\title{
The Effect of Climate Change on Australian Stock Equity Returns
}

\author{
Sveltana Vlady ${ }^{1}$
}

\begin{abstract}
:
This study investigates the climate change impact on Australian stock equity returns. This study empirically examines the effect of climate change on the Australian oil and gas industry and compares to the indexes S\&P ASX 200 and All Ordinaries, which are considered as the total indicators for the Australian equity market.

This study concludes that investors are rational. However, the climate change information is value relevant for the refining company, which is affected by Australian climate conditions. AR-GARCH model has been applied to investigate the market's response to climate change. All weather-related variables have been statistically adjusted to the climate change variables.
\end{abstract}

Key Words: Climate Change, Capital Market, Oil and Gas Industry, S\&P ASX 200 Index, All Ordinaries Index, AR-GARCH

\footnotetext{
${ }^{1}$ Department of Accounting, Finance and Economics, Griffith Business School, Gold Coast Campus,QLD, 4222, Australia, s.vlady@griffith.edu.au
} 


\section{Introduction}

Climate change is associated with an increase in global air temperature and weather extremes, and the consequences of that change (Hounghton et al., 2001). Global warming and weather extremes have taken place over the last century, and there is new, strong evidence that most of the warming over the last 50 years can be attributable to human activity (Pittock, 2003). Discernible human influences now extend to other aspects of climate change (IIPC, 2007).

The area covered by ice caps in mountainous regions has changed dramatically (Mulvaney and Golson, 1971) and there has been an extensive loss of sea ice along the north-eastern coasts of Greenland and Antarctica as well as a loss in the summer melt line in Greenland (Schiermeier, 2004). A systematic reduction in salinity, which is consistent with warmer temperatures, in the Atlantic, Pacific and Indian Oceans and the Mediterranean Sea, is evidenced (Curry et al., 2003). Extreme events are a major source of current climate impacts, and changes in extreme events such as increases in intensity of tropical cyclones and storms, and increases in the frequency of extreme high-temperature events, floods and droughts are expected to dominate the impacts of climate change (IPCC 1996; 2001).

Such climatic changes appear to have been amplified by variations in the concentration of greenhouse gases in the atmosphere. The burning of oil, coal and natural gas might cause an increase in atmospheric carbon dioxide, and hence, warm the Earth (Garratt et al., 1998). In response, a number of policies have been developed at a global and local level to encourage the reduction of global greenhouse gases emissions. In 1992, the UN Framework Convention in Rio de Janiero defined the principles which subsequently negotiated the 1997 Kyoto Protocol. The Kyoto Protocol sets legally-binding targets for developed countries to reduce greenhouse gases emissions (The Carbon Trust, 2006).

The purpose of this research is to investigate how and whether the Australian capital market responds to climate change information. The overall aim of this study is to determine the climate change impact on the market value of Australian refining company and the oil and gas industry, in comparison with the whole Australian economy.

Since the first international policy to reduce greenhouse gases emissions was introduced by the United Nations in 1992, this study empirically examines the value relevance of climate change for the period 1992 to 2006. The geographical scope of the research is Australian leading oil and gas companies operating around the world and the Australian refining company, Caltex Limited, which operates in Australia only. For comparison purposes, this research also empirically examined the value relevance of climate change of the top 200 Australian listed companies (S\&P ASX 200 Index) and 500 of the largest Australian companies across all sectors incorporated in the All Ordinaries Index. 
A significant body of academic research on the value relevance of weather, climate change and environmental issues focuses on meteorological, statistical and financial issues. There has been tremendous academic attention focused on the area of the relationship between the environment and financial performance (prize-winning studies conducted by Dowell, Hart and Yeung, 2000; Stone, Guerard, Gultekin and Adams, 2000 and many others). Numerous studies have been related to catastrophic accidents and shareholder value (Knight and Pretty, 1996; Ganzi and Dunn, 1995; Ganzi and Tanner, 1996 and others). Most research investigated the value relevance of environmental events such as oil spills, emission levels or environmental performance, however, most of the studies are not industry specific (Reed, 1998).

A number of studies have looked at the potential impact of climate change and risks and opportunities for businesses (Lanoie, Laplante and Roy, 1997; Lash and Wellington, 2007 and others). A large segment of empirical literature attempted to investigate the relationship between weather-related information and different factors such as energy demand (Valor, Meneu and Caselles, 2000; Sailor and Munoz, 1997); gas consumption (Gabbi and Znotti, 2005); prices (Roll, 1984; Boudoukh, Richardson, Shen and Whitelaw, 2005) and seasonality (Anderson, 1985; Choi and Longstaff, 1985) in weather-sensitive markets.

An increasing number of researchers in behavioural finance have empirically investigated the weather effect on an individual's emotional state, and hence, on investment decisions, by testing the different capital market indexes and stocks in different countries, regions and cities (Saunders, 1993; Kramer and Runde, 1997; Trombley, 1997; Pardo and Valor, 2003; Hieshleifer and Shumway, 2003; Tufan and Hamarat, 2004; Goetzman and Zhu, 2003; Loughran and Schultz, 2003, 2004). While some research found a significant association between weather-related information and returns, others found an insignificant relationship. Mostly these studies examined the impact of cloud cover on daily stock returns.

Keef and Roush (2002) examined weather effects that could be multifaceted and included commonly recorded weather variables. Also Keef and Roush (2005) extended their previous research and examined the different securities such as stock indexes, government bond and bank bills and deseasonaolized weather. Lather, Keef and Roush (2007) investigated the influence of the weather on the returns of two Australian stock indexes.

In addition to Keef and Roush (2007), a limited number of empirical studies investigated weather related moods and feelings on whole Australian stock returns (Worthington, 2006), weather effects on the Australian capital market (Cao and Wei, 2005) and weather effects on the returns of Australian stock indexes (Boyle and Walter, 2003; Doucouliagos, 2004). However, there are no empirical multiyear studies that examine the long-term relationship between weather change and market value on the weather-sensitive industry or company levels. 
Recently, a number of research projects on the value relevance of climate change have empirically investigated the weather and climate change impact on stock prices. Vlady (2009a) and Vlady, Roca and Tularam (2008) empirically examined and analysed the relationship between weather and climate change and shareholder value in the oil and gas industry in an Australian context. The maximum temperature was chosen as a proxy for global warming. Since the changes in atmospheric pressure signal shifts in the weather, daily pressure has been chosen as a proxy for climate change. The VAR, ARCH, AGRCH models have been applied and weatherrelated variables have not been detrended and deseasonalized to reflect seasonal weather and climate impact on the market value of weather-sensitive sectors of economy such as the oil and gas industry.

Vlady (2009a) extended the Vlady, Roca and Tularam (2008) study by using Markov Switching VAR model and confirmed the conclusion that pressure is value relevant, and investors incorporated this information for investment in the refining company, located and operating in Australia. The relationship between Australia's weather-related information and the returns on the investment of the Oil and Gas Index is not significant, due to effects on the different weather conditions around the world. However, a weather hedge could enable the weather-sensitive sector to achieve weather-dependent results stabilisation. Also, only an abnormal temperature could have an impact on the returns. Later, Vlady (2009b) investigated the value relevance of climate change and greenhouse gas emissions in the context of the Australian oil and gas industry.

However, there are no empirical multiyear studies that examine the relationship between climate change and market value on company and industry levels in comparison with the whole Australian market after greenhouse gas emission reduction policies have been introduced. Thus this study attempts to fill in this gap in the literature.

On one hand, the capital market could respond to new climate change information. On other hand, stock prices could be affected by emotional or physical changes, caused by climate conditions. If the capital market responds to new climate change information, this study expects:

(a) a significant relationship between climate change and market value of the weather-sensitive oil and gas industry and the refining company

(b) an insignificant (or less significant) relationship between climate change and market value of the largest or leading companies representing the whole of the Australian economy

If stock prices have been affected by emotional or physical conditions caused by climate conditions, thus all stocks should have the same impact on weather-sensitive industries and company, on the largest companies and on the whole market showing: 
(c) a significant relationship between climate change conditions and market value of the oil and gas industry, refining company and the whole Australian market

\begin{abstract}
AR (p)-GARCH $(1,1)$ model has been applied to investigate the market's response to climate change. All weather-related variables have been statistically adjusted to climate change variables. The Econometric Toolbox software, combined with MATLAB, Optimization Toolbox and Statistics Toolbox software have been used to analyse and perform statistical analysis.
\end{abstract}

The remaining sections are structured as follows. The following section reviews existing literature. The next section describes the data, samples and methodology. Section III outlines the results. The final section discussed the results, presents the conclusion and offers suggestions for future research.

\title{
2. Data and Methodology
}

\section{a. Data and Samples}

The Oil and Gas index and Australian refining company Caltex Limited, as well as S\&P/ASX 200 index, All Ordinaries index have been selected to investigate whether the Australian capital market incorporates climate change information into stock valuation processes after greenhouse gas reduction policies have been introduced. The share prices traded on the Australian Stock Exchange of S\&P/ASX 200, All Ordinaries, and Oil and Gas indexes and Caltex Limited were obtained from DataStream's database. Weather-related data have been provided by the Australian Bureau of Meteorology. The Sydney meteorological station was selected, since the ASX is located in Sydney.

The All Ordinaries index is considered the total market indicator for the Australian equity market. The index is comprised of the 500 largest securities listed on the ASX and the constituents are not screened for liquidity. The S\&P/ASX 200 measures the performance of the 200 largest index-eligible stocks listed on the ASX by floatadjusted market capitalization. Representative, liquid and tradable, it is widely considered Australia's preeminent benchmark index. The index is float-adjusted, covering approximately $80 \%$ of Australian equity market capitalization.

The Oil and Gas Index represents the leading Australian oil and gas companies and includes domestic companies and multinational companies that is located and operating around the world. Caltex Limited is located and operates in Australia. Australia has seven major operating refineries: BP Refinery Pty, BP Refinery Pty Ltd, (you've repeated this - both Shell Refinery and PB Refinery??) Shell Refining Pty Ltd, Shell Refining Pty Ltd, Caltex Australia Limited. Caltex is the only oil refining and marketing company listed on the Australian Stock Exchange, Australian owned and located in Brisbane and Sydney (AIP, 2005). 
To confirm or reject climate change impacts on stock prices, a set of commonly recorded data such as temperature, quality temperature, wet bulb temperature, quality wet bulb temperature, pressure, vapour pressure and humidity have been used in statistical analysis. The daily maximum temperature at 3 p.m. and, hence, all other data at 3 p.m. have been selected. All missing data have been replaced by data provided by Sydney airport's meteorological station.

All weather-related data have been detrended and deseasonalized and adjusted to 'climate change' data. Capital market returns of the Australian indexes and the Australian refining company have been calculated using the discrete return formula $\mathrm{R}_{t}=100 \ln \left(\mathrm{P}_{t} / \mathrm{P}_{t-1}\right)$ where $\mathrm{Pt}$ is the index (or company) level at the end of the day $t$. The capital market data examined in the sample are daily-end closing share prices traded on the Australian Stock Exchange. A total of 3677 daily data from July 1992 to July 2006 have been used for all returns and climate change data.

\section{b. Pre-Estimation Analysis and Descriptive Statistics}

\section{i. Pre-Estimation Analysis}

It is a well known fact that financial time series may display time-varying volatility. The most common model used to capture this phenomenon is the $\operatorname{GARCH}(1,1)$ model. An inspection of the autocorrelation functions of the returns, especially with high frequency observations, could be necessary (Thalassinos et al., 2012; 2007).

Graph 1. ACF, Return Series, Caltex Limited
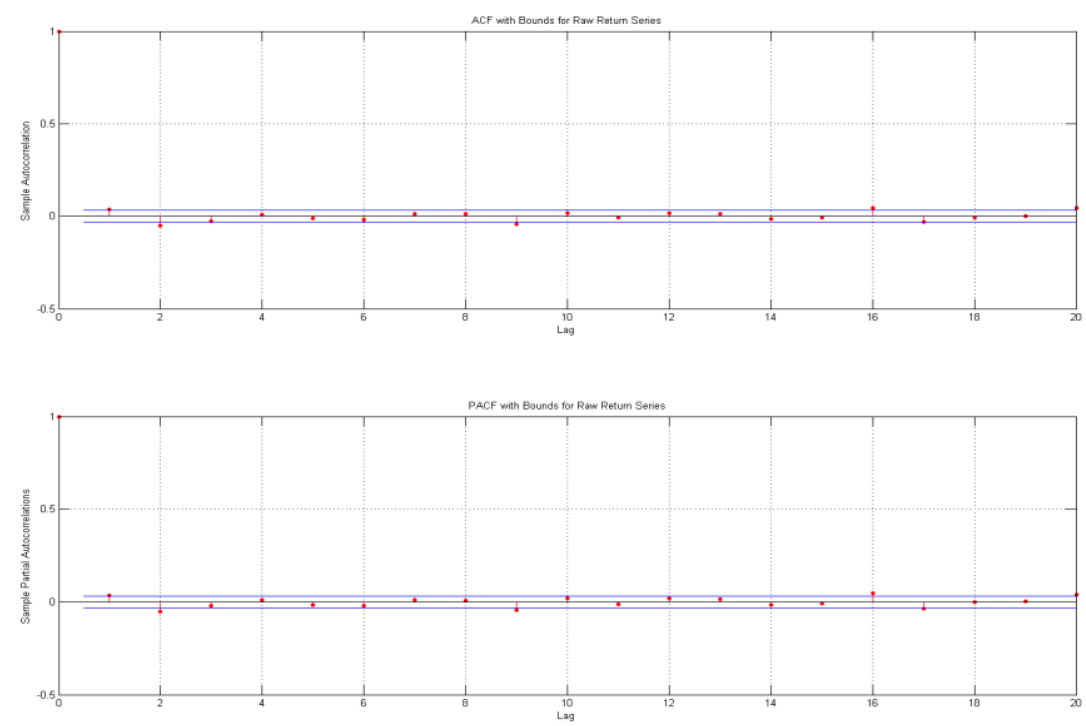
Graph 1 indicates a serial correlation with $\mathrm{t}-1$ and $\mathrm{t}-2$ and it is a positive for $\mathrm{t}-1$ and a negative for $\mathrm{t}-2$. In this equation, Rt has been regressed on $\mathrm{t}-1, \mathrm{t}-2, \mathrm{t}-3$, and so on for 30 days. The second half of the graph shows the same results, where Rt has been regressed on Rt-1 and then Rt to Rt-2 and so on.

Graph 2. ACF of the Squared Returns, Caltex Limited

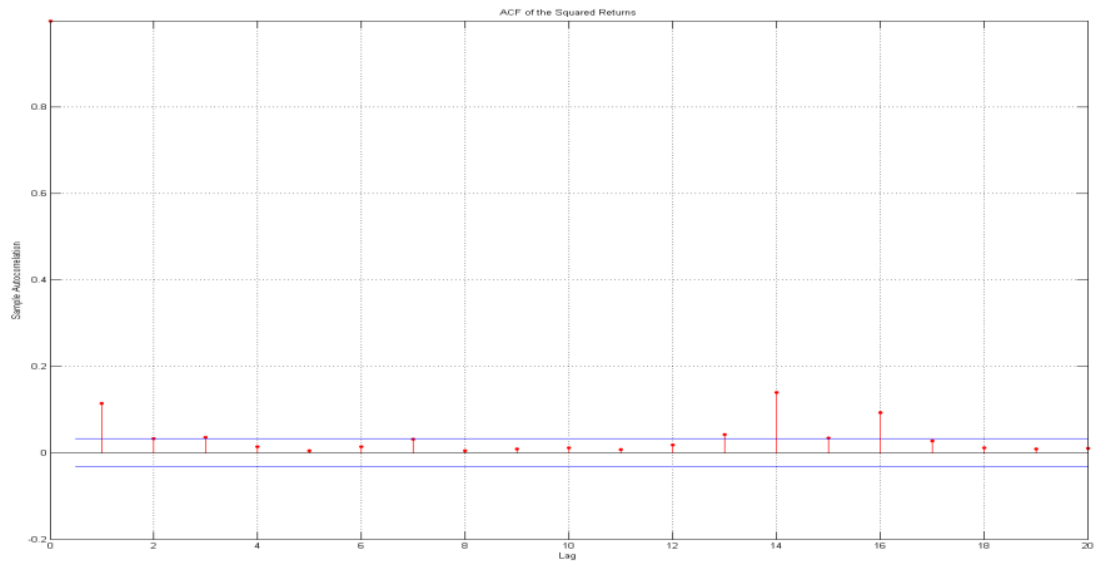

This looks at the variance of returns. It shows there is clustering of volatility with auto correlation of $\mathrm{t}-1$ and $\mathrm{t}-2$.

Graph 3. Residuals, Standard Deviation, Returns, Caltex Limited
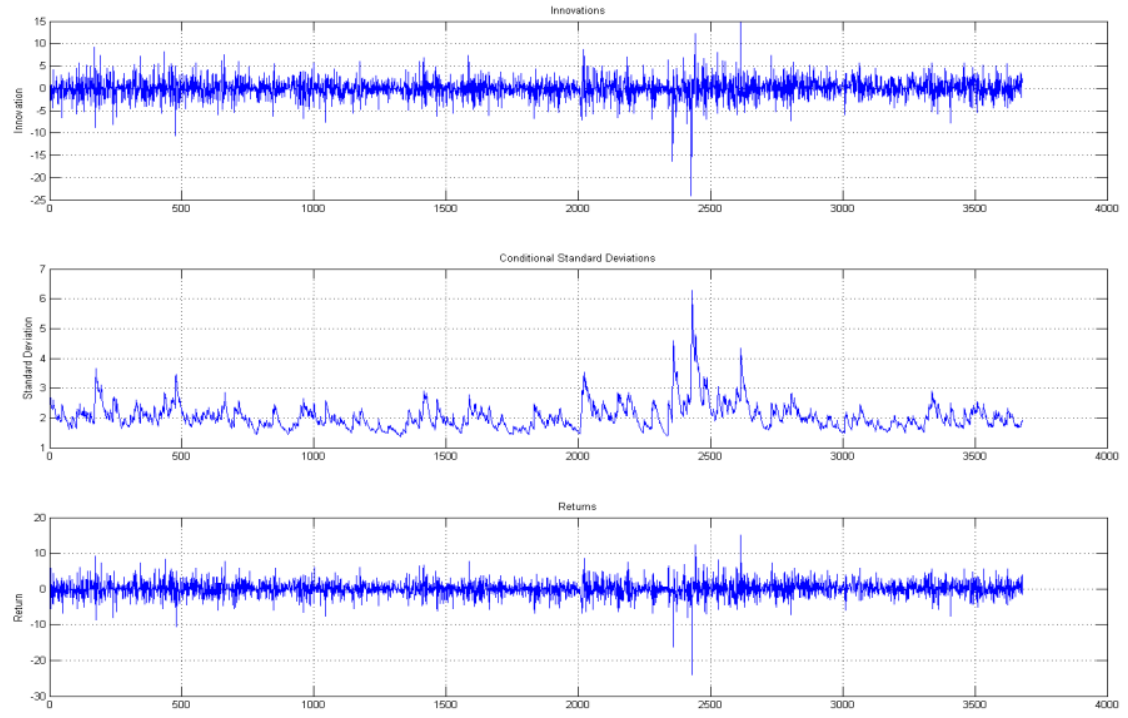
Graph 3 indicates high volatility. The first shown is in April 2000 (High Technology) and the second is a huge volatility in September 2001, followed by July-August. 2002. There are other minor levels of volatility, but these could have been caused by local shocks.

Graph 4. ACF, Return Series, Oil and Gas Index
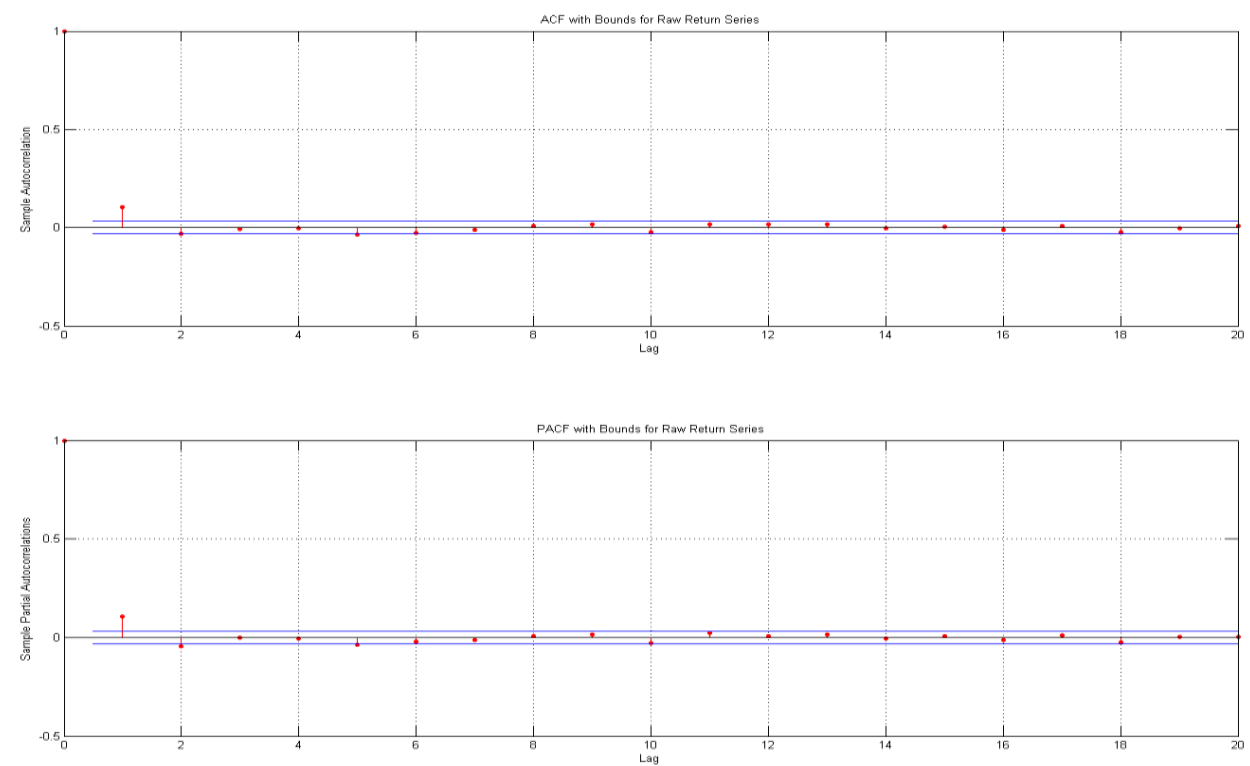

Autocorrelation $\mathrm{t}$ is a function of $\mathrm{t}-1$ and $\mathrm{t}-2$ as previously.

Graph 5. ACF of the Squared Returns, Oil and Gas Index

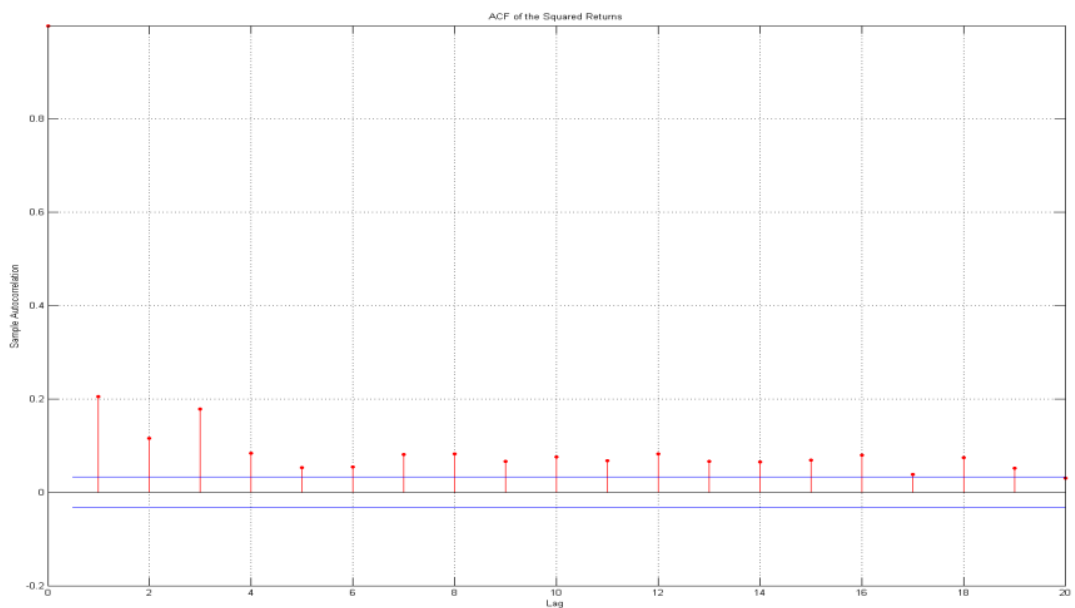


Graph 6. Residuals, Standard Deviation, Returns, Oil and Gas Index
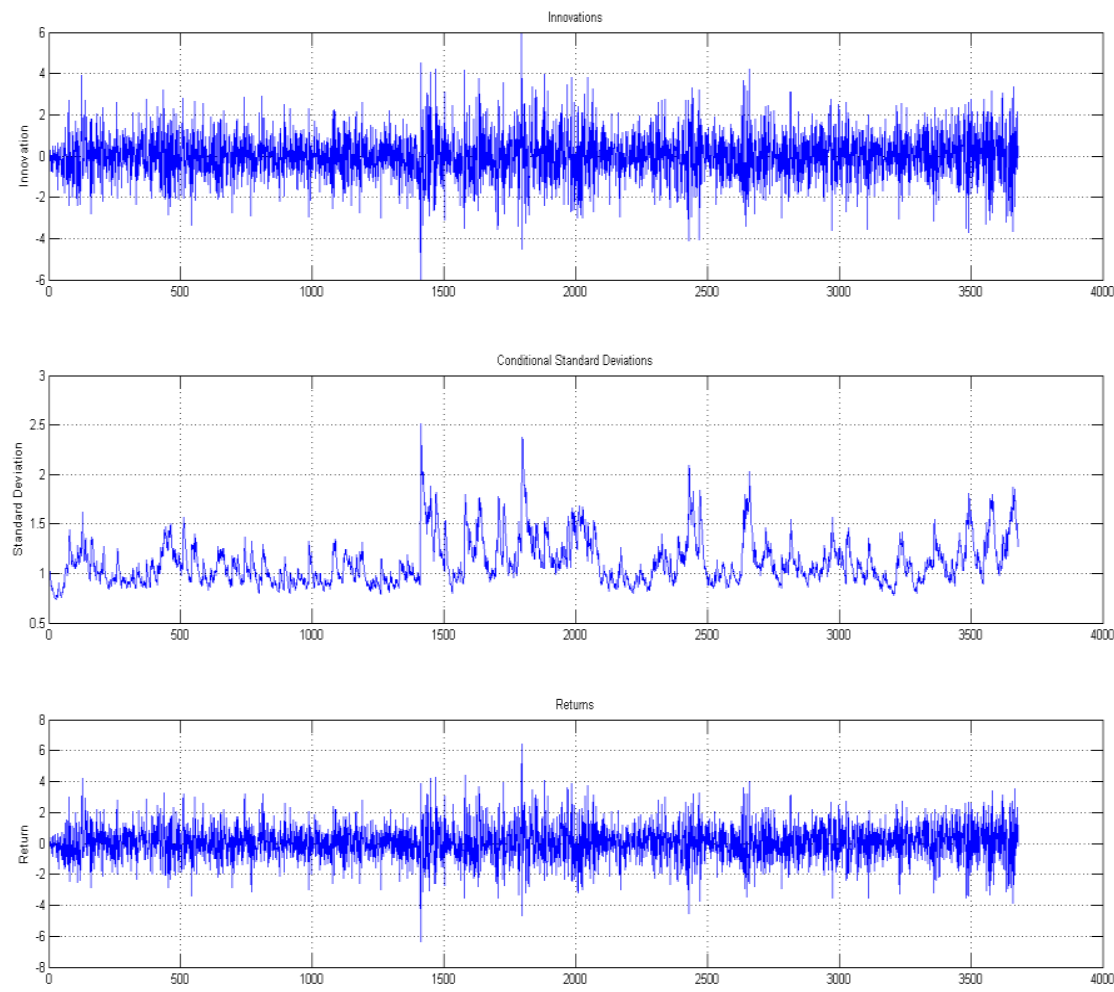

The Oil and Gas index is more affected than the refining company, Caltex Limited. The first spike is in October 1997 during the Asian Crisis. The second spike is in April 1999, the third is September 2001 and the fourth is July-August 2002. There are also indications of high volatility and some spikes from 2004 to 2006 that reflect financial and non-financial global news.

Graph 7. ACF of the Squared Returns, S\&P ASX 200 Index

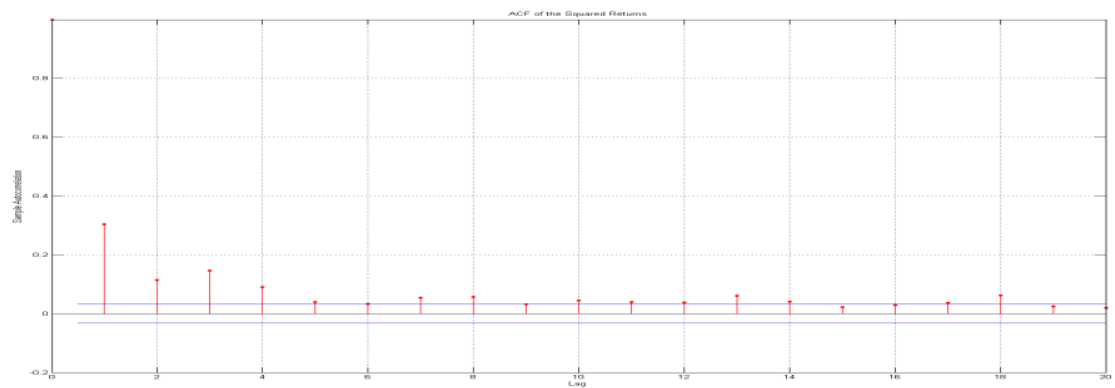


Graph 7 for S\&P ASX index illustrates high volatility and clustering, but limited and insignificant autocorrelation. This volatility persists for 3-4 days.

Graph 8. Residuals, Standard Deviation, Returns, S\&P ASX 200 Index
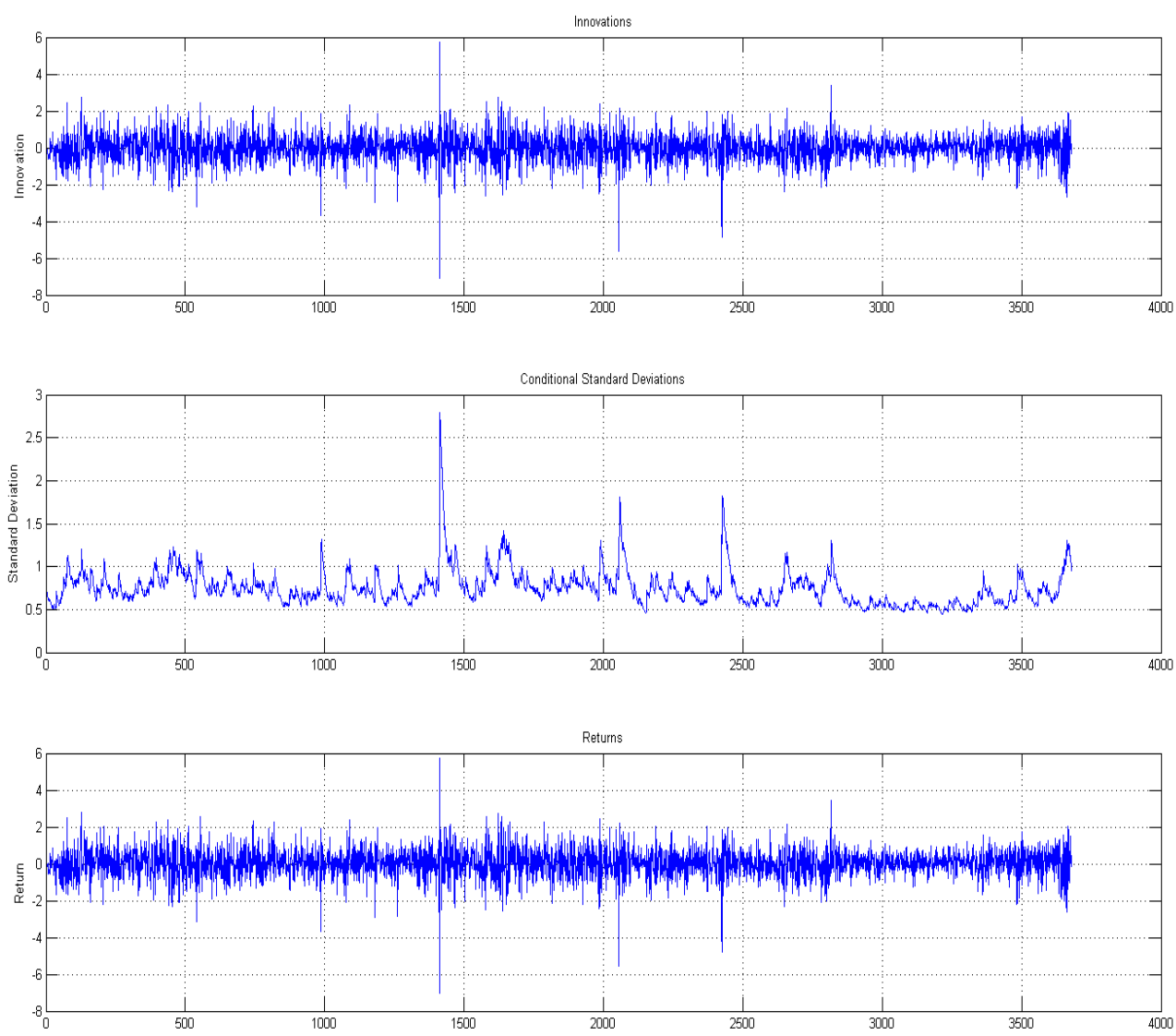

Graph 8 for the S\&P ASX 200 Index indicates the capital market's reaction and illustrates three major shocks. The first is the Asian currency crisis in October 1997. The second is the High Tech crisis of April 2000, the third is September 2001 and this followed by minor shocks in July-August 2002, spring 2003 and May 2006.

Graph 9 for the All Ordinaries Index shows that the end autocorrelations are the same as for the S\&P ASX 200 Index. 
Graph 9. ACF of the Squared Returns, All Ordinaries Index

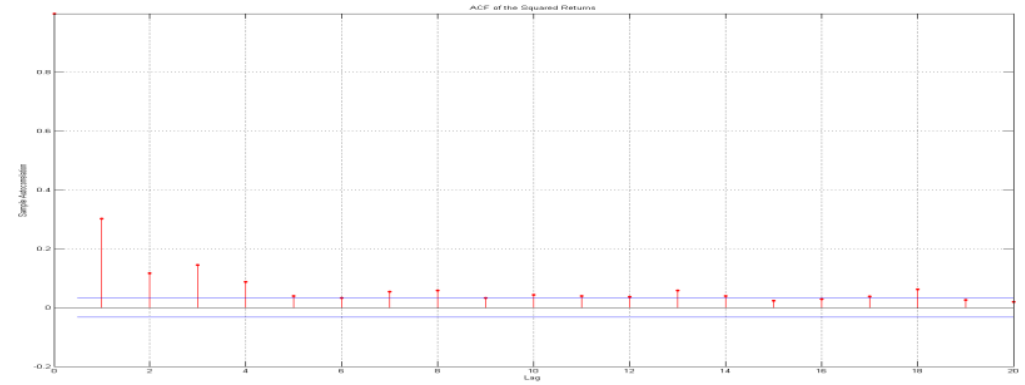

As in the graph for the S\&P ASX 200 Index, the All Ordinaries Index (graph 10) illustrates three major spikes. One is the Asian currency crisis; the second is the High Tech 2000 crisis and the third spike illustrates September 2001.

Graph 10. Residuals, Standard Deviation, Returns, All Ordinaries Index
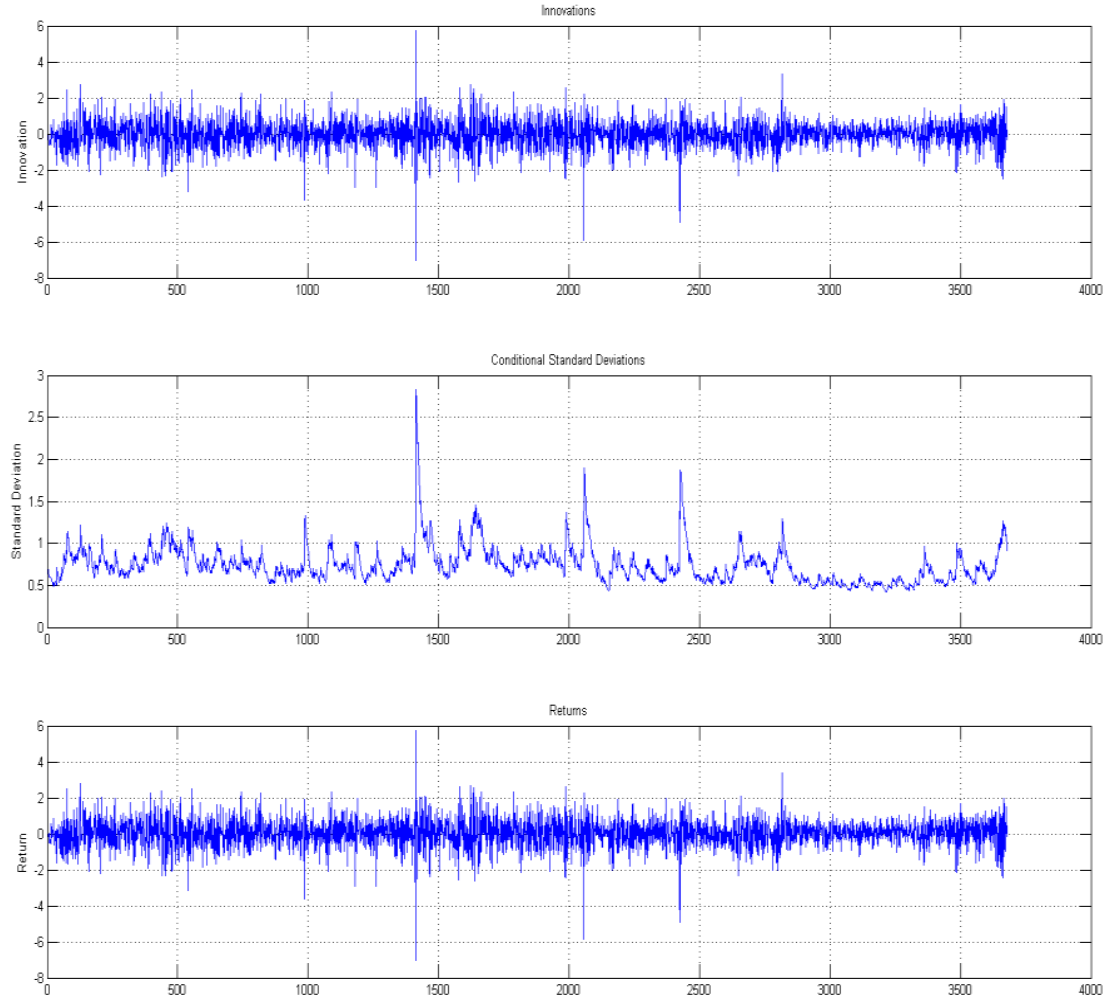


\section{Descriptive Statistics}

The descriptive statistics are presented in Table 1. Descriptive statistics of the Caltex and Oil and Gas Index returns indicate the leptokurtic or volatility clustering. Also the excess kurtosis observed in the S\&P ASX 200 Index shows persistence, which is a type of heteroskedasticity. The All Ordinaries' returns just slightly exceed the value of 3 of normal distribution. Skewness of all variables does not exceed the critical value 1.00. However, all Jarque-Bera statistics are considerably greater than the critical value of 5.99 and indicate that the data are not from a normal distribution.

Table 1. Descriptive Statistics

\begin{tabular}{|c|c|c|c|c|c|c|c|c|c|c|c|}
\hline & $\begin{array}{c}\text { Tem } \\
\text { perat } \\
\text { ure }\end{array}$ & $\begin{array}{c}\text { Qualit } \\
y \\
\text { Temp } \\
\text { eratur } \\
\text { e }\end{array}$ & $\begin{array}{c}\text { Wet } \\
\text { Bulb } \\
\text { Temp } \\
\text { eratur } \\
\text { e } \\
\text { (WBT } \\
\text { ) }\end{array}$ & $\begin{array}{c}\text { Qualit } \\
y \\
\text { WBT }\end{array}$ & $\begin{array}{c}\text { Humidit } \\
\mathbf{y}\end{array}$ & $\begin{array}{c}\text { Pressu } \\
\text { re }\end{array}$ & \begin{tabular}{|c|} 
Vapour \\
Pressure
\end{tabular} & Caltex & $\begin{array}{c}\text { Oil \&Gas } \\
\text { Index }\end{array}$ & \begin{tabular}{|c|} 
ASX2 \\
00 \\
Retur \\
n
\end{tabular} & $\begin{array}{c}\text { All } \\
\text { Ordina } \\
\text { ry }\end{array}$ \\
\hline Mean & 21.21 & 11.31 & 15.90 & 55.76 & 1010.77 & 14.24 & 25.96 & 0.0005 & 0.0035 & 0.0033 & 2848.94 \\
\hline $\begin{array}{l}\text { Media } \\
\mathrm{n}\end{array}$ & 21.00 & 12.00 & 15.90 & 56.00 & 1011.00 & 14.00 & 24.90 & 0.0000 & 0.0000 & 0.0002 & 2864.40 \\
\hline $\begin{array}{l}\text { Std. } \\
\text { Dev. }\end{array}$ & 4.23 & 5.71 & 3.71 & 16.49 & 7.34 & 5.01 & 7.04 & 0.2118 & 0.01204 & 0.0077 & 842.119 \\
\hline $\begin{array}{l}\text { Skewn } \\
\text { ess }\end{array}$ & 0.34 & -0.51 & 0.03 & -0.00 & -0.25 & 0.40 & 1.13 & -0.9121 & -1.1973 & $\begin{array}{c}- \\
0.3369\end{array}$ & 0.61 \\
\hline $\begin{array}{l}\text { Kurtosi } \\
\text { S }\end{array}$ & 3.13 & 2.84 & 2.23 & 2.99 & 2.97 & 4.50 & 5.61 & 14.93 & 32.35 & 7.30 & 3.11 \\
\hline $\begin{array}{l}\text { Jarque- } \\
\text { Bera }\end{array}$ & 74.30 & 166.40 & 91.53 & 0.001 & 39.69 & 451.93 & \begin{tabular}{|l|}
1836.17 \\
\end{tabular} & 38530.2 & 323503.0 & $\begin{array}{c}2909.7 \\
3\end{array}$ & 236.26 \\
\hline
\end{tabular}

\section{Methodology and Empirical Results}

\section{a. $\operatorname{AR}(\mathbf{p})$ - GARCH $(1,1)$ Model}

The volatility clustering, serial correlation and heteroskedasticity in refining company and all indexes in the GARCH model, and the presence of autocorrelation in Caltex's and Oil and Gas Index's stock returns, suggests the inclusion of an 
Autoregressive component $\mathrm{AR}(\mathrm{p})$ In order to investigate a relationship between returns on investments in refining company Caltex Limited and the Oil and Gas Index and climate change, an autoregressive dynamic and conditional heteroskedasticity have been incorporated and AR(p) - GARCH $(1,1)$ model has been selected.

The present volatility and heteroskedasticity indicates that GARCH $(1,1)$ model is appropriate for the market indexes S\&P/ASX 200 and All Ordinaries. Independent weather-related variables have been detrended and deseasonalized to become the same as the climate change variables.

In the context of this study, the model takes the following specification:

$$
\begin{gathered}
\mathrm{R}_{i, t}=\alpha+\varphi_{1} \mathrm{R}_{i, t-p}+\beta_{1} \mathrm{X}_{1, t}+\beta_{2} \mathrm{X}_{2, t}+\beta_{3,} \mathrm{X}_{3 t}+\beta_{4,} \mathrm{X}_{4 t}+\beta_{5,} \mathrm{X}_{5 t}+\beta_{6,} \mathrm{X}_{6 t}+\beta_{7,} \mathrm{X}_{7 t}+\mathrm{e}_{i, t} \\
\sigma^{2}{ }_{t i}=\kappa+\theta_{1} \sigma_{\mathrm{i}, \mathrm{t}-1}^{2}+\theta_{2} \mathrm{e}^{2}{ }_{\mathrm{i}, \mathrm{t}-1} \quad \mathrm{i}=1,2,3,4
\end{gathered}
$$

In (1), $\mathrm{R}$ are returns, $\mathrm{X} 1$ is temperature, $\mathrm{X} 2$ pressure, $\mathrm{X} 3$ is humidity, $\mathrm{X} 4$ is quality of air temperature, X5 is wet bulb temperature, X6 is quality of wet bulb temperature and $\mathrm{X} 7$ is vapor pressure. $\mathrm{i}$ is the return subscript (1=Caltex, 2=O\&G index, 3=SP200, 4=All500). Also an AR(p) component is allowed in the conditional mean equation.

To estimate the model the following procedure has been applied:

1. Remove linear trends and seasonal patterns in weather-related and carbon emission variables.

2. Calculate dummy variables for each period (days, weeks, months).

3. Regress the independent variables $X_{n, t}$ on dummy variables and use residuals as the independent variables in (2.1) model.

4. Apply AR (p) - GARCH $(1,1)$ or GARCH $(1,1)$ regression models to estimate models (1) and (2).

5.

Thus, the standard strategy is to regress the independent variables on dummy variables. $\mathrm{D}_{n, t}$ has been used and the following model has been applied:

$\mathrm{X}_{t}=\delta \mathrm{t}+\theta_{1} \mathrm{D}_{1, t}+\theta_{2} \mathrm{D}_{2, t}+\ldots+\theta_{n} \mathrm{D}_{n, t}+\varepsilon_{t}$

where $\delta \mathrm{t}$ is the trend, $\mathrm{D}_{n, t}$ are the weekly 'dummy' variables, $n$ is the number of weeks. There are 52 dummies for this single variable, instead of 365 dummies.

Finally, the residuals $\varepsilon_{t}$ from equation (3) have been used as independent variables $\mathrm{X}_{n, t}$ in model (1). Thus, the residuals from equation (3) became the explanatory variables in equation (1). 


\section{b. Empirical Results}

The value relevance of climate change results in the context of the Australian refining company, the Australian oil and gas industry, leading Australian companies and the whole Australian market are presented in Table 2. Results indicate that that climate change is value relevant only for the refining weather-sensitive company Caltex. The coefficients that are statistically significant are humidity $0.14895(\mathrm{t}=$ $2.0284)$, temperature $0.30611(\mathrm{t}=1.6694)$, wet bulb temperature $-0.4295(\mathrm{t}=-$ $1.7475)$. Caltex's return of $-0.05538(-2.9381)$ is inversely correlated with the previous day's return.

Table 2. Value Relevance of Climate Change

$$
\begin{gathered}
\mathrm{R}_{i, t}=\alpha+\phi_{1} \mathrm{R}_{i, t-p}+\beta_{1} \mathrm{X}_{1, t}+\beta_{2} \mathrm{X}_{2, t}+\beta_{3,} \mathrm{X}_{3 t}+\beta_{4,} \mathrm{X}_{4 t}+\beta_{5,} \mathrm{X}_{5 t}+\beta_{6,} \mathrm{X}_{6 t}+\mathrm{e}_{i, t} \\
\sigma^{2}{ }_{t i}=\mathrm{k}+\theta_{1} \sigma^{2}{ }_{i, \mathrm{t}-1}+\theta_{2} \mathrm{e}^{2}{ }_{i, \mathrm{t}-1} \\
\mathrm{X}={ }_{i t} \delta \mathrm{t}+\theta_{1} \mathrm{D}_{1, t}+\theta_{2} \mathrm{D}_{2, t}+\ldots+\theta_{52} \mathrm{D}_{52, t}+\varepsilon_{i, t}
\end{gathered}
$$

\begin{tabular}{|c|c|c|c|c|}
\hline & Caltex & OGI & S\&P ASX 200 & All Ordinaries \\
\hline $\begin{array}{l}\text { Constant } \\
\text { (t-stat) }\end{array}$ & $\begin{array}{l}0.08209 \\
(2.5283)\end{array}$ & $\begin{array}{l}0.04750 \\
(2.6928)\end{array}$ & $\begin{array}{l}0.04755 \\
(3.9943)\end{array}$ & $\begin{array}{l}0.04877 \\
(4.1959)\end{array}$ \\
\hline $\begin{array}{l}\text { AR (1) } \\
(\text { t-stat) }\end{array}$ & $\begin{array}{l}-0.05538 \\
(-2.9381)\end{array}$ & $\begin{array}{l}0.10962 \\
(6.4280)\end{array}$ & & \\
\hline $\begin{array}{l}\text { Temperature (T) } \\
(\text { t-stat) }\end{array}$ & $\begin{array}{l}0.30611 \\
(1.6694)\end{array}$ & $\begin{array}{l}0.06759 \\
(0.4969)\end{array}$ & $\begin{array}{l}-0.04851 \\
(-0.6462)\end{array}$ & $\begin{array}{l}-0.04326 \\
(-0.5760)\end{array}$ \\
\hline $\begin{array}{l}\text { Pressure } \\
\text { (t-stat) }\end{array}$ & $\begin{array}{l}-2.1062 \mathrm{e}-005 \\
(-0.0174)\end{array}$ & $\begin{array}{l}0.00036 \\
(0.2702)\end{array}$ & $\begin{array}{l}0.00070 \\
(0.5511)\end{array}$ & $\begin{array}{l}0.00066 \\
(0.5406)\end{array}$ \\
\hline $\begin{array}{l}\text { Humidity } \\
\text { (t-stat) }\end{array}$ & $\begin{array}{l}0.14895 \\
(2.0284)\end{array}$ & $\begin{array}{l}0.04631 \\
(0.8926)\end{array}$ & $\begin{array}{l}0.00777 \\
(0.2668)\end{array}$ & $\begin{array}{l}0.00976 \\
(0.3362)\end{array}$ \\
\hline $\begin{array}{l}\text { Quality of air T } \\
\text { (t-stat) }\end{array}$ & $\begin{array}{l}0.02442 \\
(0.5250)\end{array}$ & $\begin{array}{l}-0.00076 \\
(-0.0272)\end{array}$ & $\begin{array}{l}-0.00376 \\
(-0.2123)\end{array}$ & $\begin{array}{l}-0.00378 \\
(-0.2172)\end{array}$ \\
\hline
\end{tabular}




\begin{tabular}{|c|c|c|c|c|}
\hline $\begin{array}{l}\text { Wet bulb T (WBT) } \\
\text { (t-stat) }\end{array}$ & $\begin{array}{l}-0.42995 \\
(-1.7475)\end{array}$ & $\begin{array}{l}-0.10394 \\
(-0.5714)\end{array}$ & $\begin{array}{l}0.02446 \\
(0.2452)\end{array}$ & $\begin{array}{l}0.01808 \\
(-1.1972)\end{array}$ \\
\hline $\begin{array}{l}\text { Quality of WBT } \\
\text { (t-stat) }\end{array}$ & $\begin{array}{l}0.00406 \\
(0.3607)\end{array}$ & $\begin{array}{l}0.00025 \\
(0.0351)\end{array}$ & $\begin{array}{l}-0.00533 \\
(-1.2659)\end{array}$ & \begin{tabular}{|l}
-0.00497 \\
$(-1.1972)$
\end{tabular} \\
\hline $\begin{array}{l}\text { Vapor pressure } \\
\text { (t-stat) }\end{array}$ & $\begin{array}{l}-0.07053 \\
(-1.6501)\end{array}$ & $\begin{array}{l}-0.01502 \\
(-0.5163)\end{array}$ & $\begin{array}{l}0.01132 \\
(0.6560)\end{array}$ & $\begin{array}{l}0.01022 \\
(0.5945)\end{array}$ \\
\hline $\begin{array}{l}K \\
(t-s t a t)\end{array}$ & $\begin{array}{l}0.14141 \\
(7.0265)\end{array}$ & $\begin{array}{l}0.54175 \\
(5.2665)\end{array}$ & $\begin{array}{l}0.01578 \\
(5.1394)\end{array}$ & $\begin{array}{l}0.01360 \\
(5.1980)\end{array}$ \\
\hline $\begin{array}{l}\text { GARCH(1) } \\
\text { (t-stat) }\end{array}$ & $\begin{array}{l}0.91221 \\
(118.5552)\end{array}$ & $\begin{array}{l}0.87966 \\
(63.0038)\end{array}$ & $\begin{array}{l}0.89641 \\
(90.4998)\end{array}$ & $\begin{array}{l}0.89753 \\
(97.6828)\end{array}$ \\
\hline $\begin{array}{l}\text { ARCH(1) } \\
(\text { t-stat) }\end{array}$ & $\begin{array}{l}0.05665 \\
(12.5425)\end{array}$ & $\begin{array}{l}0.07851 \\
(9.4163)\end{array}$ & $\begin{array}{l}0.07906 \\
(13.0088)\end{array}$ & $\begin{array}{l}0.08176 \\
(13.5105)\end{array}$ \\
\hline
\end{tabular}

Climate change appears to be not relevant for the weather-sensitive oil and gas industry. The results show that the oil and gas industry's return $0.10962(\mathrm{t}=6.4280)$ is significant and positively correlated with the previous day's return. ARCH results appears to be significant for Caltex and the oil and gas companies, and indicates that today's volatility has an impact over the next day's volatility. A significant GARCH shows that today's volatility is correlated with the previous day's volatility for Caltex and the Oil and Gas Index.

Results reveal that climate change does not significantly impact the leading Australian companies and the whole Australian market. The sum of ARCH (1) and GARCH (1) coefficients around 1 (0.97) are statistically significant and indicate that Australia's 200 leading and 500 largest companies have persistent volatility and variance. The capital market has reacted on past shocks and news and is affected by variance from the last period. However, this variance does not stem from climate change.

Climate change appears to be irrelevant for the weather-sensitive oil and gas industry. The results show that the oil and gas industry's return $0.10962(\mathrm{t}=6.4280)$ is significant and positively correlated with the previous day's return. ARCH appeared to be significant for Caltex and the oil and gas companies and indicates that today's volatility has an impact over the next day's volatility. A significant 
GARCH shows that today's volatility is correlated with the previous day's volatility for Caltex and the Oil and Gas Index.

Results reveal that climate change does not significantly impact leading Australian companies or the whole Australian market. The sum of ARCH (1) and GARCH (1) coefficients around $1(0.97)$ is statistically significant and indicates that Australia's 200 leading and 500 largest companies have persistent volatility and variance. The capital market reacted on past shocks and news and is affected by variance from the last period. However, this variance does not stem from climate change.

Moreover, with highly correlated explanatory variables the multicollinearity problems might incur, i.e. standard errors tend to be larger inducing a high probability of type II error (retaining the null hypothesis when it is false). Correlations of the explanatory variable are presented in Table 3.

Table 3. Multicolliniearity

\begin{tabular}{|c|c|c|c|c|c|c|c|}
\hline & $\begin{array}{c}\text { Temperatur } \\
\text { e }\end{array}$ & \begin{tabular}{|c|} 
Pressur \\
e
\end{tabular} & $\begin{array}{c}\text { Humidit } \\
y\end{array}$ & $\begin{array}{c}\text { Quality Air } \\
\text { Temperatur } \\
\text { e }\end{array}$ & $\begin{array}{c}\text { Wet Bulb } \\
\text { Temperatur } \\
\text { e }\end{array}$ & \begin{tabular}{|c|} 
Qualit \\
y of \\
WBT
\end{tabular} & $\begin{array}{c}\text { Vapour } \\
\text { pressur } \\
\text { e }\end{array}$ \\
\hline $\begin{array}{l}\text { Temperatur } \\
\text { e }\end{array}$ & 1 & 0.15 & 0.10 & 0.05 & 0.63 & 0.48 & 0.97 \\
\hline Pressure & 0.15 & 1 & 0.11 & 0.08 & 0.18 & 0.16 & 0.72 \\
\hline Humidity & 0.10 & 0.11 & 1 & 0.96 & 0.83 & 0.76 & 0.08 \\
\hline $\begin{array}{l}\text { Quality Air } \\
\text { Temperatur } \\
\text { e }\end{array}$ & 0.05 & 0.08 & 0.96 & 1 & 0.79 & 0.79 & 0.03 \\
\hline $\begin{array}{l}\text { Wet Bulb } \\
\text { Temperatur } \\
\text { e }\end{array}$ & 0.63 & 0.17 & 0.83 & 0.79 & 1 & 0.34 & 0.59 \\
\hline Quality of & -.048 & 0.16 & 0.76 & 0.79 & 0.34 & $\overline{1}$ & -0.47 \\
\hline
\end{tabular}




\begin{tabular}{|l||c|c|c|c|c|c|c|}
\hline WBT & & & & & & & \\
\hline $\begin{array}{l}\text { Vapour } \\
\text { Pressure }\end{array}$ & 0.97 & 0.07 & 0.08 & 0.03 & 0.59 & -0.47 & 1 \\
\hline
\end{tabular}

The results presented in Table 3 indicate a high correlation between variables that are related to temperature, such as quality of air temperature, wet bulb temperature, quality of wet bulb temperature, vapour pressure. Also, the results suggest that variables such as temperature, pressure and humidity are less correlated and would be appropriate for future statistical analysis.

\section{Discussion}

The empirical results support the prediction of this study that climate change is value relevant, and that investors incorporate climate change information into stock financial assessments of the refining company Caltex Limited. However, climate change information appears to be insignificant for oil and gas companies. Nevertheless, the results of this study are consistent with the conclusions of Vlady, Roca and Tularam (2008) and Vlady (2009a). The refining company Caltex Limited is located and operates in Australia only, but the oil and gas index includes multinational companies which are operated around the world and which are affected by different weather conditions and climatic extremes.

Consistent with Vlady's (2009b) results, the level of humidity that is actually associated with weather forecasting is significant. Temperature and other related variables such as wet bulb temperature and vapour pressure are also significant on a 5 per cent level of significance. Humidity is an important metric used in forecasting weather conditions (Australian Bureau of Meteorology, 2009), and it indicates the likelihood of precipitation, dew or fog (Wikipedia, 2009). Moreover, the weather conditions depend on both the temperature and the humidity and thus, the wet-bulb temperature is probably its best indicator (Australian Bureau of Meteorology, 2009).

Refining and oil and gas companies rely on weather forecasts to anticipate demand which can be significantly affected by extreme weather. Severe cold weather or unusual hot summer temperatures can cause a surge in demand with an increased use of heating or air conditioning. By anticipating an increase in demand, the refining company can purchase additional supplies of oil or natural gas before the price increase. It is consistent with Vlady's (2008) and Cao and Wei's (2005) conclusion that only extreme temperatures could have an impact on the returns, and high humidity and abnormal temperature could affect the demand for petroleum and gasoline and could therefore be important for the refining company in determining demand. 
Barometric pressure, which usually signals a the change in the weather, doesn't appear to be significant for the oil and gas index, and it is inconsistent with Vlady's (2009a,b) results. A significant change in pressure predicts a significant change in the weather and is associated with rains, storms, cyclones and high wind. All these extreme events are formed in areas of low pressure. Nevertheless, there are a few spikes in December 2004, August-October 2005 and December-January 2006 which could be associated with the 2004 Indian Ocean tsunami (26 December 2004), hurricane Katrina (August 2005, USA), hurricane Rita (September 2005, USA), hurricane Wilma (October 2005, USA) and hurricane Zeta (December 2005, USA). Australian oil and gas multinational companies have many subsidiaries in the United States and traffic in imported petroleum. However, consistent with multicollinearity analysis and Worthington's (2006) conclusion, results could be affected by high correlation between explanatory variables. Moreover, oil and gas companies operate around the world and are affected by different climatic conditions, and are also able to hedge weather risk (Vlady, 2009).

Also, the empirical results support the prediction of this study that the relationship between climate change and Australian market returns is not statistically significant, or is less significant and consistent with Worthington (2006) and Cao and Wei (2005). The Australian S\&P ASX 200 Index covers approximately 80 per cent of Australian equity cap and captures a broad market representation. The All Ordinaries Index includes 500 of the largest Australian listed ASX companies and is considered to be the overall Australian stock market. Extreme weather events are actually bad for business and could decrease productivity, lower profit and increase the costs of running businesses. However, each of the weather-sensitive businesses that contribute to the economy have a different definition of "bad weather". For some companies "bad weather" can actually be good for business (Sinsky, 2008). The following Table 4 presents the weight of each sector in the S\&P ASX 200 Index. Some sectors are weather sensitive and others are not.

Table 4. GICS as A Percentage Of S\&P/ASX 200

\begin{tabular}{|l|c|}
\hline Sector & Per cent \\
\hline Health Care & $2.5 \%$ \\
\hline Consumer Discretionary & $11 \%$ \\
\hline Consumer Staples & $7.0 \%$ \\
\hline Property Trusts & $8.0 \%$ \\
\hline Financials excluding Property Trusts & $35.2 \%$ \\
\hline Information Technology & $0.5 \%$ \\
\hline
\end{tabular}




\begin{tabular}{|l|c|}
\hline Telecommunication Services & $5.6 \%$ \\
\hline Utilities & $1.2 \%$ \\
\hline Energy & $2.7 \%$ \\
\hline Materials & $19.2 \%$ \\
\hline Industrials & $7.1 \%$ \\
\hline
\end{tabular}

However, Keef and Roush found that the returns of the Australian market could be influenced negatively by deseasonalized temperatures. They used a repeated measure design to estimate the standard errors of the coefficients and concluded that "increased temperature influences the physiology of investors" and "psychoeconomic depression leads to a weakening in prices on the Australian stock exchange" (p.181).

However, the results of this study are inconsistent with Keef and Roush's (2007) conclusion, and support the prediction that if stock prices have been affected by physical conditions caused by climate conditions, then all stocks should have approximately the same impacts on companies, the industry, and the whole market. The results revealed that stock prices are affected differently, even though the financial centre is located in Sydney, and buyers and sellers around Australia and international investors should not be affected by the temperature in Sydney.

Theories of human behaviour from anthropology, psychology and sociology have motivated empirical research on the behaviour of financial markets. The behaviour principles include prospect theory, regret and cognitive dissonance, anchoring, mental compartments, overconfidence, over- and under-reaction, gambling behaviour, magical and quasi-magical thinking, culture and social contagion and so on (Shiller, 1997). Behaviour finance assumes that investors are irrational. In contrast, the Efficient Market Theory assumes that investors behave rationally and predictably in an efficient market which adjusts rapidly to new information.

Moreover, economics professor Paul Krugman detects "The Seven Habits of Highly Defective Investors" that make markets anything but efficient: think short-term, be greedy; behave in the grater fool; run with the herd; over-generalize, be trendy; and play with other people's money (Lebaron, 1999).

The analysis and results of this study indicate that investors reacted to the financial crises and financial and non-financial news, and that the market is efficient. Also, investors are rational and incorporate climate change information into the stock valuation process of the weather/climate-sensitive refining company. Moreover, investors use forecasting information to make rational investment decisions. Future 
research could investigate how climate change and carbon emissions information will be incorporated at the company, industry and whole market levels by investors, after the Kyoto Protocol has been signed

\section{References}

AIP (Australian Institute of Petroleum), 2006, "Submission to the inquiry into the price of petroleum in Australia", Federal Parliament (Senate Economics Committee), August. Retrieved on April 9, 2007 from http//www.aipea.com.au

Anderson, R., 1985, "Some determinants of the volatility of futures prices", Journal of Futures Markets 5, 332-348.

Australian Bureau of Meteorology, 2009, Forecasting the weather. Australian Government. Retrieved on April 2009 http:/www.bom.gov.au/info/ftweather

Boudoukh, J., Richardson, M. Shen, Y. and R. Whitelaw, 2005, "Do asset prices reflect fundamentals? Freshly squeezed evidence from OJ market", Journal of Financial Economics 83(2), 271-530.

Boyle, G. and B. Walter, 2003, "Reflected glory and failure: international sporting success and the stock market", Applied Financial Economics 4, 297-304.

Cao, M. and J. Wei, 2005, "An expended study on stock market temperature anomaly", Research in Finance 22, 73-112.

Choi, J. and F. Longstaff, 1985, "Pricing options on agricultural futures: An application of the constant elasticity of variance option pricing model", Journal of Futures Markets 5, 247-258.

Curry, R., Dickson, B. and I. Yashayaev, 2003, "A change in the freshwater balance of the Atlantic Ocean over the past four decades", Nature 426, 826-829.

Doucouliagos, H., 2004, "Number preference in Australian stocks", Applied Financial Economics 14, 43-54.

Dowell, G., Hart, S. and B. Yeung, 2000, "Do corporate global environmental standards create or destroy market value?", Management Science 46, 8.

Gabbi, G. and G. Znotti, 2005, June, "Climate variables and weather derivatives: Gas demand, temperature and seasonality effects in the Italian case", 2005 Annual Conference, University Boccony, Milan, Italy.

Ganzi, J. and J. Tanner, 1996, 'Global survey on environmental policies and practices of the financial service industry: The private sector", Washington, DC: National Wildlife Federation.

Garratt, J., Prata, A., Rotstayn, L., McAvaney, B.J. and S. Cusack, 1998, "The surface radiation budget over oceans and continents", J. Climate 11, 1951-1968.

Goetzmann, W. and N. Zhu, 2005, "Rain or shine: Where is the weather effect?", European Financial Management 5 (11), 559-578.

Hirshlefer, D. and T. Shumway, 2003, "Good day sunshine: Stock returns and the weather", Journal of Finance 3(8), 1009-1039.

Houghton, J., Ding, Y., Griggs,D., Noguer, N., van der Linden, X., Dai, K. , and C. Johnson, (eds) 2001, "The Scientific Basis. Contribution of Working Group I to the Third Assessment Report of the Intergovernmental Panel on Climate Change (Cambridge University Press, Cambridge, United Kingdom and New York, NY, USA).

IPCC (Intergovernmental Panel on Climate Change), 2001, "Climate Change 2001: Impacts, Adaptation, and Vulnerability", Contribution of Working Group II to the Third Assessment Report of the Intergovernmental Panel on Climate Change [McCarthy, 
J.J., O.F. Canziani, N.A. Leary, D.J. Dokken, and K. White (eds), (Cambridge University Press, Cambridge, United Kingdom and New York, NY, USA).

IPCC (Intergovernmental Panel on Climate Change), 2007, "Climate Change 2007: The physical science basis", Contribution of working Groupl to the Fourth Assessment Report of the Intergovernmental Panel on climate change, (Cambridge University Press, Cambridge, United Kingdom and New York, NY, USA).

Keef, S. and M. Roush, 2002, "The weather and stock return in New Zealand", Quarterly Journal of Business and Economics 41, 61-79.

Keef, S. and M. Roush, 2005, "The influence of weather on New Zealand financial securities", Accounting and Finance 45, 415-437.

Keef, S. and M. Roush, 2005, "Daily weather effect on returns of Australian stock indices", Applied Financial Economics 17, 173-184.

Knight, R. and D. Pretty, 1996 , "The impact of catastrophes on shareholders". Retrieved on September 10, 2007, from www.rothstein.com/links/rothstein.

Kramer, W. and R. Runde, 1997, "Stock and the weather: An exercise in data mining or yet another capital market anomaly?", Empirical Economics 22, 637-641.

Lash, J. and F. Wellington, 2007, "Competitive advantage on warming planet", Harvard Business Review March 1.

Lebaron, D., 1999, "Market Efficiency", Retrieved 20 September, 2007 from http://www.deanlebaron.com/book/ultimate/chapters/mkt_eff.html; Paul Krugman's website http:// www.ssrn.com (website of the Social Science Research Network).

Loughran, T. and P. Schultz, 2003, "Weather, stock returns, and the impact of localized trading behaviour", Journal of Financial and Quantitative Analysis 39, 343-640.

Mulvaney, D. and J. Golson, (eds) 1971, "Aboriginal man and Environment in Australia", Australian National University Press, Canberra.

Pardo, A. and E. Valor, 2003, "Spanish stock returns: Rational or weather influence?", European Financial Management 9(2), 78-84.

Pittock, A., 2003, "Climate change: an Australian guide to the science and potential impacts", Canberra, ACT: Australian Greenhouse Office. 239 p. http://www.greenhouse.gov.au/science/guide

Reed, D., 1998, “Green shareholder value: Hype or hit?” Washington: World Resources Institute.

Roll, R., 1984, Orange Juice and weather, American Economic Review 74, 861-880.

Sailor, D. and J. Munoz, 1997, "Sensitivity of electricity and natural gas consumption to climate in the USA- methodology and results for eight states", Energy 22, 987-998.

Saunders, E., 1993, "Stock prices and Wall Street weather", American Economic Review, 83(5), 1337-1345.

Schiermeier, Q., 2004, “Arising tide”, Nature 428, 114-115.

Shiller, R., 1997, "Human behaviour and the efficiency of the financial system", Conference Recent Developments in Macroeconomics at the Federal Reserve Bank of New York, February 27-28, 1997.

Sinsky,R., 2008, When bad weather is good for US business. Retrieved on January 2009, from www.weatherbill.com

Stone B., Guerard, J., Gultekin, M., and G. Adams, 2000, "Socially responsible investment screening: Strong empirical evidence of no significant cost for managed value-focused portfolios", Working Paper, June 2001.

actively

Thalassinos, I.E., Hanias P.M. and Curtis G.P., 2012, Time series prediction with neural networks for the Athens Stock Exchange indicator, European Research Studies 
Journal, 15(2), 23-31.

Thalassinos, E.J., Hanias, P.M., Curtis, G.P., 2007, Non-linear dynamics and chaos: The case of the price indicator at the Athens Stock Exchange. International Research Journal of Finance and Economics, 11(1), 154-163.

The Carbon Trust, 2006, "Business Responses to Global Climate Change", London: The Carbon Trust, Retrieved on August 8, 2007 http:/www.carbontrust.co.uk

Trombley, M., 1997, "Stock prices and Wall Street weather. Additional evidence", Quarterly Journal of Business and Economics 36(1), 11-21.

Tufan, E. and B. Hamarat, 2004, "Do cloudy days affect stock exchange returns?: Evidence from Istanbul Stock Exchange", Journal of Naval Science and Engineering 2(1), $117-126$.

Valor, E., Meneu, V. and V. Caselles, 2001, "Daily air temperature and electricity load in Spain", Journal of Apply Meteorology 40, 1413-1421.

Vlady, S., 2009a, "The value relevance of climate change: A preliminary study of oil and gas companies in Australia", Oil, Gas \& Energy Quarterly 57(4), 711-735.

Vlady, S., 2009b, "The value relevance of climate change and greenhouse gases emissions: Evidence from Australian oil and gas industry", American Accounting Association 2009 Annual Meeting, August 1-5, 2009, New York City, NY, USA.

Vlady, S., Roca, E. and G. Tularam, 2008, "The market value of Australian oil and gas industry and climate change: The VAR, ARCH AND GARCH approaches", Studies in Regional \& Urban Planning (SRUP) 11b (December), 195-220.

Wikipedia (The free encyclopedia), 2007, "Weather forecasting", Retrieved on 26 December, 2007, from http://www.e.wilipedia.org/wiki

Worthington, A., 2006, "Whether the weather: A comprehensive assessment of climate effects in the Australian stock market", University of Wollongong, School of Accounting and Finance Working Paper Series No. 06/17, 2006. 